\title{
FROM LINEAR TO CIRCULAR ECONOMY: THE ROLE OF REGIONAL AWARENESS AND INITIATIVES
}

\author{
Louis Delcart 1 (iD)
}

${ }^{1}$ Board Member European Academy of the Regions \& Visiting Lecturer Brussels Diplomatic Academy V.U.B Brussels, Belgium.

Received 5 September 2021

Accepted 16 September2021

Published 30 September2021

\section{CorrespondingAuthor \\ Louis Delcart, lodelcar@gmail.com \\ DOI \\ 10.29121/granthaalayah.v9.i9.2021. 4238}

Funding: This research received no specific grant from any funding agency in the public, commercial, or not-for-profit sectors.

Copyright: (C) 2021 The Author(s). This is an open access article distributed under the terms of the Creative Commons Attribution License, which permits unrestricted use, distribution, and reproduction in any medium, provided the original author and source are credited.

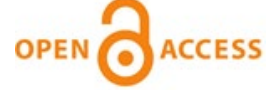

\section{ABSTRACT}

Although many OECD countries are working on it, the economy is only slowly developing from linear to circular. However, many economists are convinced that this is the only viable path if we want to prevent a climate catastrophe by 2050 and thereby leave a habitable and developable world for the next generations. Numerous articles in the press point out that many companies are only at the beginning of a gigantic effort to make their production $\mathrm{CO} 2$ neutral but also sustainable and that a lot of innovation will be needed before that happens. So, what are the reasons why the transition towards a circular economy is so difficult to make?

The European Academy of the Regions, that advocates the regionalisation of a number of economic and socio-cultural sectors, closely follows the development of the circular economy. Since the beginning of May 2021, it has therefore set-up a blog in which newspaper articles are translated from various countries to English with examples of successful circular economy initiatives or of critical studies: earaercircular.tumblr.com. To date, the organisation made a statistical study on the 100 selected articles ${ }^{1}$ published between 3/5/2021 and 3/9/2021 that will give the reader an idea of the themes that are most frequently discussed and of the remedies that are created. The articles come from newspapers and magazines from Belgium (Dutch and French), the Netherlands, Germany, Spain and the US and to a lesser extent from Switzerland, Canada and France. The results of this research are an overview of the topics covered, of indications of how initiatives are created, who is the influencer as well as an overview of the articles that have received more than 100 clicks on social media.

It has been striking that many of the initiatives described by the press have arisen from companies whose top management is aware of the bend that urgently needs to be made and who also see commercial opportunities to start early. There are also a number of cooperative initiatives, that still succeed in creating successful initiatives from a small-scale approach. A second important player in this conversion is the academic world, especially faculties or even entire universities that have been conducting research into new materials or new applications for a long time. The traditional third player are the authorities, but very often regional governments or large cities.

The conclusion remarks show that circular economy can only be successful if companies see a profit model in it, or are forced to change their course by public opinion because of negative perception and that we are not yet there.

Keywords: Linear, Circular, Economy, Awareness, Initiatives

\section{INTRODUCTION}

Louis Delcart, board member European Academy of the Regions, www.ear-aer.eu Although many OECD countries are working on it, the economy is only slowly developing from linear to circular. However, many economists are convinced that this is the only viable path if we want to prevent a climate catastrophe by 2050 
and thereby leave a habitable and developable world for the next generations. Numerous articles in the press point out that many companies are only at the beginning of a gigantic effort to make their production $\mathrm{CO} 2$ neutral but also sustainable and that a lot of innovation will be needed before that happens. So, what are the reasons why the transition towards a circular economy is so difficult to make? This article attempts to provide an overview of the causes.

\section{THE 3 R'S}

Not every country is as far along when it comes to introducing a circular economy. Prof. dr. Herminio Sastre, director of the Chair of Circular Economy at the University of Oviedo (Spain) and professor of Environmental Technology, sums up the three principles again in an article published this year in El País: Reducir, Reutilizar y Reciclar ${ }^{2}$ or Reduce, Reuse and Recycle.

And although the same professor points out in the same article that this is a principle already successfully used by our grandparents to minimize the waste they produced, there are big differences between the period of those grandparents and the present one. Our grandparents lived close to the land on which food was harvested, bought utensils and furniture that were often still produced in workshops no more than two hundred kilometres from their home, and spent most of their income in shops situated within 1 kilometre of their home. They could also call on repairmen such as electricians, mechanics or plumbers who gave the best of their capacities to get the appliances working again. One of the indictments of the students in May 68 was a cry against the emerging consumption society. Multiple were already the closures of factories in textiles, mechanics, metallurgy throughout Europe and America. Many utensils, products, food, etc. that we currently consume as families were now produced on an industrial scale, often even far from home, or with parts that have completed a 4-month sea voyage. The post-industrial consumption society has also become a throwaway society, with concepts such as fast food, fast fashion and even fast furniture.

It is only from the second decade of the twenty-first century that the multinationals that had hitherto been geared to a type of hyper-consumption and also stimulated this behaviour, were confronted with a call for change. Their first reaction has been one of greenwashing: pretending. Poignant examples are H\&M and Ikea that supposedly greened their production, but only did this with words. And after a while the other - smaller - companies looked down on this fake behaviour. Because studies from independent research institutes such as the British Eco-Age were published that denounce such practices. ${ }^{3}$

And here we come to the core of our argument: the evolution from linear economy to circular economy cannot be imposed from above and must also be developed from an economically sound model. An example is packaging: in Europe there has been a trend for twenty years - and later laid down in European directives - to make the polluter pay for the processing of his waste. Organizations have therefore arisen in every country, in which the business sectors are the shareholders, to recover the packaging of their goods and even recover the entire discarded goods. And they have to do something with that: so, a thinking about recycling has arisen based on the principles mentioned above: Reduce, Reuse and Recycle. A recycling industry has thus emerged that is achieving great first successes. This process has not yet started in the US: the companies left the recovery of packaging to the local government, which sold it to China. It was a non-profit operation that should cost the municipalities and counties nothing. Until at the end of 2018, China closed the door to American packaging and municipalities were saddled with a recycling hangover. It is only now, 2021, that a number of states (New 
York, California, Indiana, Massachusetts, Maine and Oregon) are starting to take steps to copy the European - and also Canadian - "polluter pays" ${ }^{4}$ model. 5

\section{CIRCULAR ECONOMY: WHAT IS IT REALLY ABOUT?}

Québec Circulaire, a group of French-Canadian organizations focused on the transition to this new mode, defines the circular economy as follows: "New economic model aimed at decoupling economic growth from natural resource depletion and environmental impact through two main mechanisms: 1) Rethinking our production-consumption methods to consume fewer resources and protect the ecosystems that generate them 2) Optimize the use of resources already circulating in our societies." 6

Our organisation, European Academy of the Regions, that advocates the regionalisation of a number of economic and socio-cultural sectors, closely follows the development of the circular economy. The reader will notice later that the most successful initiatives are taken by regions and/or cities. Since the beginning of May 2021, we have therefore set-up a blog in which newspaper articles are translated from various countries to English with examples of successful circular economy initiatives or of critical studies: earaercircular.tumblr.com.

\section{RESEARCH ABOUT PRESS INTEREST ON CIRCULAR ECONOMY AND CREATION OF AWARENESS}

To date, we have made a statistical study on the 100 selected articles 7 published between 3/5/2021 and 3/9/2021 that will give the reader an idea of the themes that are most frequently discussed and of the remedies that are created. The articles come from newspapers and magazines from Belgium (Dutch and French), the Netherlands, Germany, Spain, France and the US and to a lesser extent from Switzerland and Canada. Here is an overview of the topics covered:

\begin{tabular}{|c|c|c|}
\hline Global topic & Topics & Number of occurences \\
\hline Reuse & $\begin{array}{l}\text { food waste, thrift shopping, recycling, second } \\
\text { hand clothing, refurbished devices }\end{array}$ & 25 \\
\hline Innovation & $\begin{array}{l}\text { C02 Compensation, disposable packaging, } \\
\text { green chemistry, hemp benefits, sustainable } \\
\text { alternatives, bioplastics, sustainable } \\
\text { furniture }\end{array}$ & 12 \\
\hline Water management & $\begin{array}{l}\text { groundwater management, waste water } \\
\text { management, heat networks }\end{array}$ & 11 \\
\hline Circular building & $\begin{array}{l}\text { redevelopment projects, sustainable } \\
\text { construction, circular building }\end{array}$ & 10 \\
\hline Farming & $\begin{array}{l}\text { biomass, classical biocontrole, aquaponics, } \\
\text { short food circuit, sustainable food, system, } \\
\text { urban farming }\end{array}$ & 7 \\
\hline $\begin{array}{l}\text { Circular economy } \\
\text { promotion }\end{array}$ & $\begin{array}{l}\text { circularity, composting, ecnomic advantages } \\
\text { of circular economy }\end{array}$ & 7 \\
\hline Negative elements & Deforestation, plastic waste & 4 \\
\hline Recycling materials & $\begin{array}{l}\text { matrasses, electric cars, flood waste, ocean } \\
\text { plastic, recycling packaging, sustainable } \\
\text { fashion, recycling furniture, recycling } \\
\text { plastics, battery recycling, sustainable } \\
\text { shopping, waste treatment, recycled plastics, } \\
\text { recycling textile, waste processing, recycling }\end{array}$ & 1 \\
\hline
\end{tabular}




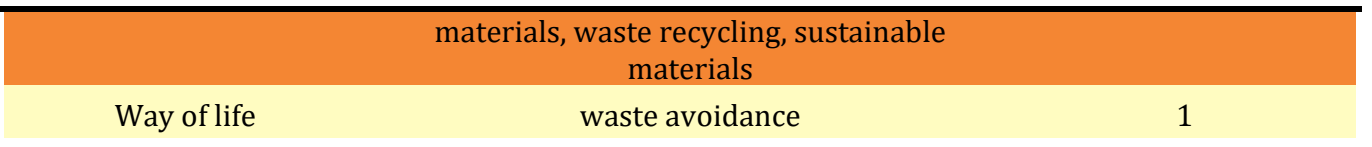

As a Dutch article $^{8}$ from the very useful electronic newsletter Change Inc already points out: there is a lot of good will, but a lot still needs to be achieved, especially when it comes to circular techniques such as the reuse of materials: plastics in the first place, since there are 80,000 different types that are often used in combination and the result of which becomes difficult to recycle, batteries in the second place, which in turn gives electric cars an Achilles heel, concrete in the third place because breaking down and clearing sorted rubble is a perilous and therefore expensive undertaking. Textiles, on the other hand, are going in the right direction, especially when it comes to natural yarns, jeans are a headache because they are run through by chemicals, among other things to stretch them. ${ }^{9}$ It is very striking that so few articles are devoted to innovations, not because universities do not work on them, but mainly because it is the large companies that do not want to invest in completely new production processes. Small-scale agriculture is regularly brought to the attention, but does not appeal to the general public so much: it is difficult and an important effort to make time for varied shopping. We feel that especially avoiding plastic packaging has become a hype that consumers are starting to pay attention to. But here too, according to Rogers' innovation theory ${ }^{10}$, we are still only in the stage of the innovators and early adapters and it is the first hesitant early majority that should start to act. Circular business models such as leasing ${ }^{11}$ sofas or electrical appliances instead of buying them, allowing manufacturers to take them back and rearrange them, has so far been a theory that has been implemented only very modestly. The share economy is gradually getting underway, especially with bicycles and steps in cities. But is it sustainable in view of the multiple abandoned pieces alongside the road.

\section{TECHNOLOGY AS AN ACCELERATOR OF PROCESSES AND BUSINESS MODELS?}

Large companies that are serious about their transition to a circular economy are using technological innovation as an ally to accelerate. The strategy often is based on four axes. Ecodesign: The products are based on approaches that meet sustainability criteria from birth, allowing them to extend their service life and increase the subsequent recycling of their components. Efficiency and innovation of processes: it is about optimizing resources and processes so that waste is given a new destination. Renewable energy and alternative raw materials: Renewable energy sources and raw materials of residual origin are used in the manufacture of the products. New consumption patterns: Initiatives are promoted that prioritize renting over product purchases, promoting more responsible consumption. 12

Pressured by public opinion that has reacted scandalously to the news that returns from e-commerce for fashion brands have been incinerated, major brands have turned to technology that allows a customer to better see how a garment would fit on his/her body. Zalando wants to integrate that technology on its platform. Clothing chain H\&M is also developing such a virtual fitting room. It is not yet known when these developments will be ready for use. ${ }^{13}$ 


\section{CIRCULAR ECONOMY: THE TRIPLE HELIX ONCE AGAIN}

In our study, we also pay attention to indications of how initiatives are created, who is the influencer:

\begin{tabular}{|cc|}
\hline Initiator/Influencer & Number of articles in which mentioned \\
\hline company initiative & 50 \\
\hline regional approach & 39 \\
\hline academic contribution & 17 \\
\hline public agencies & 16 \\
\hline public controle institutes & 8 \\
\hline Governments + companies, smart cities & 4 \\
\hline ngo initiative & 3 \\
\hline reverse logistics & 2 \\
\hline
\end{tabular}

These are very striking results. Many initiatives have arisen from companies whose top management is aware of the bend that urgently needs to be made and who also see commercial opportunities to start early. They are often supported by their trade association, especially when the industry has a large number of financially strong players, who allocate sufficient resources to their trade association to carry out R\&D or have it done. They also influence legislative initiatives by speaking out for or against them. In the discussion about levying a deposit for beverage cans in France, a large number of industry associations spoke out in favour of introducing this. ${ }^{14}$ The industry associations of professionals in the recycling industry, on the other hand, expressed their reluctance. In the US, the lobby group Ameripen, a group of stakeholders from the packaging industry ${ }^{15}$, has recently suggested that they are open to the idea of EPR, extended producer responsibility (see above).

There are also a number of cooperative initiatives, mainly in southern Europe, that still succeed in creating successful initiatives from a small-scale approach. The large Basque cooperative bus builder Irizan is collaborating with the Spanish public transport company Iberdrola in a plan for city buses, battery recycling and smart charging network ${ }^{16}$. La Fabrique Circuit Court in the province of Namur in Belgium brings together cooperative processing workshops, independent workshops and logistics spaces. All committed to the short food chain. An indispensable link for small artisan producers ${ }^{17}$. In Antwerp, a cooperative association Warmte Verzilverd has persuaded the multinational Agfa-Gevaert to use its residual heat in a new residential area a few kilometres away ${ }^{18}$.

A second important player in this conversion is the academic world, especially faculties or even entire universities that have been conducting research into new materials or new applications for a long time, such as Wageningen and Saxion in the Netherlands, BOKU in Vienna, Hochschule München, Universities of Ghent and Antwerp, Aalto in Finland, Oviedo in Spain, etc. Large NGOs also contribute by commissioning studies: WWF, Greenpeace, Ellen MacArthur Foundation, etc. The initiatives sometimes come from the university itself, sometimes on behalf of companies or industry associations, sometimes from regional authorities with sufficient funds, but they are stimulating.

Many universities are taking initiatives to make their students, and thus future managers and engineers, aware of a change in attitude both privately and in the 
economy in order to promote the circular economy. For example, all universities and technical universities in the German state of Brandenburg have developed initiatives to consciously encourage their students to develop different ways of living. Solar systems, environmental management, special degree programs, changed menu in the cafeteria: for universities and technical universities in Brandenburg, climate neutrality and sustainability in the course of study are very topical. Even the organization for student facilities, Studentenwerk Potsdam, is also enthusiastically participating in this: it draws energy from 100 percent green electricity, it recycles the wastewater from the showers and hand basins, it managed that solar thermal energy on the roof of the older building also benefits the new dormitory, all plastic bottles and tetrapaks are currently being removed from the range and replaced in the cafetarias by more sustainable glass bottles and every Wednesday in the eight canteens and eight cafeterias run by the Studentenwerk, only meat-free meals are served. 19

The traditional third player are the authorities, but very often regional governments or large cities. They stimulate by doing seed financing. The Walloon and Brussels governments in Belgium have thus set up and provided means for several public agencies to link circular economy projects to social projects ${ }^{20} \cdot{ }^{21} \mathrm{But}$ also, by enacting local regulations. For example, the government of Flanders imposes through its public tenders 22 that new public construction initiatives are to be realised on the principles of the circular economy. As a result, contractors are forced to organize themselves in a certain direction. The city of Apeldoorn in the Netherlands, on the other hand, put out a tender ${ }^{23}$ to realize a link between its database with all existing building materials in public space and a digital marketplace. This makes it possible to trade released materials so that they can be reused elsewhere.

The same often happens in France and in Spain where it is the regions and/or departments that are pioneers in encouraging universities and industries to take initiatives to convert the linear economy into a more climate-friendly and planetfriendly circular economy.

\section{CIRCULAR ECONOMY AND AWARENESS}

During the exercise, we not only translated the 100 articles into English and published them on tumblr.com but also on LinkedIn where we have more than 2000 followers. LinkedIn's statistics also allow us to find out how many contacts clicked on the article and thus were interested in it and how many also liked the article. Traditionally this is 2 to $3 \%$. Here is an overview of the articles that have received more than 100 clicks.

The result indicates that there are no topics that appeal more than others. From second-hand clothing, to recycling garbage, water and concrete, cleaning the soil by plants, the reuse of PET bottles by the industry: it attracts the interest of many. It is clear that we have entered an era where, admittedly in Western Europe, a certain category of people is taking an effective interest in all initiatives taken to bring the climate challenge under control, even if it will affect their own way of life. 


\begin{tabular}{|c|c|c|c|c|c|c|c|}
\hline Title & Topic & Newspaper & Country newspaper & Cases from & Date & Views & Likes \\
\hline Voka study: circular economy is becoming contagious & recycling & Trends & B & B & $16 / 06 / 2021$ & 361 & 6 \\
\hline $\begin{array}{l}\text { Between emergency and ecology, how to recycle the } \\
\text { mountain of waste formed by the floods? }\end{array}$ & emergency & LLB & B & B & $20 / 07 / 2021$ & 333 & 4 \\
\hline \begin{tabular}{|l|l} 
Will plants also soon remove PFOS from the soil? \\
\end{tabular} & phytoremediation & De Standaard & $B$ & $B, F$ & $31 / 07 / 2021$ & 328 & 4 \\
\hline Fashion recycling in the Bahnwärter Thiel in Munich & second hand clothes & SDZ & D & $\mathrm{D}$ & $26 / 08 / 2021$ & 253 & 2 \\
\hline $\begin{array}{l}\text { What is the future for the ruins of houses after the } \\
\text { floods? }\end{array}$ & sustainable construction & De Standaard & B & E, B, USA & $24 / 07 / 2021$ & 244 & 2 \\
\hline $\begin{array}{l}\text { Plastic bottle tyres: Continental in favour of using } \\
\text { recycled PET }\end{array}$ & recycled plastic & SDZ & D & D,USA,F & $3 / 08 / 2021$ & 224 & 2 \\
\hline $\begin{array}{l}\text { Green façade that purifies shower water and insulates } \\
\text { the house? UGhent pilot project turns out to be a } \\
\text { success }\end{array}$ & waste water treatment & VRTNews & B & B & $12 / 07 / 2021$ & 221 & 3 \\
\hline $\begin{array}{l}\text { Antwerp organises action to throw waste in the } \\
\text { garbage can outdoors as well }\end{array}$ & waste recycling & De Standaard & B & B & $2 / 07 / 2021$ & 210 & 3 \\
\hline $\begin{array}{l}\text { Ocean Cleanup's second attempt to remove plastic } \\
\text { from the sea is now in full swing }\end{array}$ & ocean plastic & Change Inc & $\mathrm{NL}$ & $\mathrm{NL}$ & $12 / 08 / 2021$ & 209 & 7 \\
\hline Dutch biomass causes deforestation in Estonia & deforestation & Trouw & $\mathrm{NL}$ & NL, EST & $7 / 07 / 2021$ & 201 & 1 \\
\hline $\begin{array}{l}\text { Processing } 150,000 \text { tonnes of flood waste will take up } \\
\text { to a year }\end{array}$ & waste treatment & LLB & B & B & $11 / 08 / 2021$ & 190 & 3 \\
\hline Sustainable fashion or a haven for quacks? & sustainable fashion & De Standaard & $B$ & GB & $30 / 06 / 2021$ & 189 & 1 \\
\hline The obstacle course to 'green' Lego blocks & recycled PET bottles & De Tijd & $B$ & $\mathrm{DK}, \mathrm{B}$ & $23 / 06 / 2021$ & 185 & 3 \\
\hline $\begin{array}{l}\text { True price: the solution for food prices that are too } \\
\text { low }\end{array}$ & sustainable food system & Change Inc. & $\mathrm{NL}$ & $\mathrm{NL}$ & $2 / 07 / 2021$ & 184 & 1 \\
\hline E-cars are better than their reputation & battery recycling & SDZ & $\mathrm{D}$ & $D$ & $21 / 07 / 2021$ & 181 & 1 \\
\hline Ecological building from old concrete & circular building & SDZ & $\mathrm{D}$ & D & $16 / 07 / 2021$ & 179 & 3 \\
\hline $\begin{array}{l}\text { Fashion brands are diving into ocean plastic, but does } \\
\text { it really save the oceans? }\end{array}$ & ocean plastic & Knack WE & B & GB & 9/07/2021 & 177 & 1 \\
\hline $\begin{array}{l}\text { Recycling in America Is a Mess. A New Bill Could Clean } \\
\text { It Up. }\end{array}$ & waste processing & NYT & USA & USA & $27 / 01 / 2021$ & 176 & 3 \\
\hline What can cardboard furniture do? & recycling materials & SDZ & $\mathrm{D}$ & $\mathrm{D}$ & $30 / 07 / 2021$ & 174 & 2 \\
\hline “Green Amazon" launched by two Belgians & impact entrepreneurship & LLB & $B$ & $B, F$ & $8 / 08 / 2021$ & 170 & 1 \\
\hline 'We really need to get rid of that plastic now' & plastic waste & Change Inc. & $\mathrm{NL}$ & A & $16 / 07 / 2021$ & 163 & 3 \\
\hline $\begin{array}{l}\text { Dutch Municipality launches database and } \\
\text { marketplace for circular materials } \\
\end{array}$ & circular building & Change Inc. & $\mathrm{NL}$ & $\mathrm{NL}$ & $7 / 07 / 2021$ & 160 & 1 \\
\hline $\begin{array}{l}\text { 'The ban on washing cars with tap water was just a } \\
\text { foretaste' }\end{array}$ & water management & De Tijd & B & $B, L$ & $27 / 07 / 2021$ & 155 & 2 \\
\hline $\begin{array}{l}\text { Elephant grass stores four times as much } \mathrm{CO} 2 \text { as a } \\
\text { forest. This company therefore wants to plant it on all } \\
\text { wasteland. }\end{array}$ & $\mathrm{CO} 2$ compensation & Change Inc. & $\mathrm{NL}$ & $\mathrm{NL}$ & $8 / 07 / 2021$ & 153 & 0 \\
\hline Make Brussels an orchard city & urban farming & LLB & $B$ & $B$ & $5 / 07 / 2021$ & 152 & 2 \\
\hline $\begin{array}{l}\text { When what your grandparents did was the basis of the } \\
\text { circular economy }\end{array}$ & composting & El Pais & E & E, NL, FIN & $18 / 03 / 2021$ & 150 & 2 \\
\hline The nasty consequences of fast furniture & recycling furniture & Trouw & $\mathrm{NL}$ & $\mathrm{NL}$ & $21 / 08 / 2021$ & 150 & 2 \\
\hline $\begin{array}{l}\text { When what your grandparents did was the basis of the } \\
\text { circular economy }\end{array}$ & waste recycling & El Pais & $E$ & E, NL, FIN & $18 / 03 / 2021$ & 150 & 2 \\
\hline $\begin{array}{l}\text { The not so circular journey of household waste in } \\
\text { Spain }\end{array}$ & circularity & El Pais & E & $\mathrm{E}$ & $2 / 05 / 2021$ & 140 & 0 \\
\hline The Cotton Tote Crisis & recycling textile & NYT & USA & $\begin{array}{l}\text { USA, DK; CDN, } \\
\text { S, AUD }\end{array}$ & $1 / 09 / 2021$ & 140 & 5 \\
\hline $\begin{array}{l}\text { Clean and safe city center through smart waste } \\
\text { collection and digital innovation }\end{array}$ & waste recycling & Change Inc. & $\mathrm{NL}$ & $\mathrm{NL}$ & $15 / \mathrm{jul} / 21$ & 139 & 2 \\
\hline Food waste app & waste food & SDZ & $\mathrm{D}$ & DK & $24 / 07 / 2021$ & 134 & 0 \\
\hline The Circular Economy of Recycled Paper & company initiative & NYT & USA & $\mathrm{NL}$ & $18 / 11 / 2014$ & 133 & 1 \\
\hline $\begin{array}{l}\text { Maine Will Make Companies Pay for Recycling. Here's } \\
\text { How It Works. }\end{array}$ & recycling materials & NYT & USA & USA & $21 / 07 / 2021$ & 133 & 0 \\
\hline $\begin{array}{l}\text { Water from plastic bottles has hundred times more } \\
\text { impact on the environment than tap water }\end{array}$ & plastic waste & Change Inc. & $\mathrm{NL}$ & $\mathrm{NL}, \mathrm{E}$ & $6 / 08 / 2021$ & 125 & 5 \\
\hline $\begin{array}{l}\text { Returns are free, but that sweater that didn't fit might } \\
\text { go into the incinerator }\end{array}$ & waste management & Trouw & $\mathrm{NL}$ & NL,UK & $16 / 08 / 2021$ & 119 & 0 \\
\hline $\begin{array}{l}\text { This start-up wants to empower the business of } \\
\text { refurbished mobile phones and tablets }\end{array}$ & refurbished laptops & LLB & B & B & $27 / 07 / 2021$ & 115 & 0 \\
\hline The Beauty Brands Cutting Down on Packaging & disposable packaging & NYT & USA & USA,DK,I & $14 / 07 / 2021$ & 106 & 2 \\
\hline $\begin{array}{l}\text { At the initiative of Dutch Agricultural University, } \\
\text { science and industry make hard plastic from } \\
\text { agricultural waste }\end{array}$ & bioplastics & Change Inc. & $\mathrm{NL}$ & $\mathrm{NL}$ & $26 / 07 / 2021$ & 105 & 0 \\
\hline $\begin{array}{l}\text { Repairing electrical appliances is becoming easier in } \\
\text { France and in Europe }\end{array}$ & reuse & InfoduJour & $\mathrm{F}$ & $F, E U$ & $20 / 04 / 2021$ & 105 & 3 \\
\hline $\begin{array}{l}\text { Things are not yet running smoothly within the circular } \\
\text { economy }\end{array}$ & waste avoidance & SDZ & D & D & $20 / 08 / 2021$ & 105 & 1 \\
\hline $\begin{array}{l}\text { At the initiative of Dutch Agricultural University, } \\
\text { science and industry make hard plastic from } \\
\text { agricultural waste }\end{array}$ & waste recycling & Change Inc. & $\mathrm{NL}$ & $\mathrm{NL}$ & $26 / 07 / 2021$ & 105 & 0 \\
\hline Iberdrola and Irizar join forces in electric mobility & battery recycling & El Pais & $\mathrm{E}$ & $\mathrm{E}$ & $20 / 07 / 2021$ & 101 & 0 \\
\hline
\end{tabular}




\section{CIRCULAR ECONOMY: WHAT CONTRIBUTIONS CAN REGIONS MAKE?}

As already mentioned, there are numerous puzzle pieces that all need to fit together. The first part concerns the collection and processing of waste. Although separate waste collection is promoted in the EU, this is often still very rudimentary in many member states. Composting is one of the basic activities that a family with a house can do themselves. There are also towns such as Vitoria in the Spanish Basque Country that offer communal composting services, for those who live in an apartment and don't have space to compost. The municipality installs these devices in certain parts of the city and users only have to go there to deposit organic waste. Disused clothing or electrical/electronic equipment should also be taken care of by the local authorities. ${ }^{24}$ Electronic components and clothing go to the container parks 25 that the municipalities have built in different parts of each city. Separate collection is being implemented even more thoroughly in thirty Dutch cities. Where in the past they mainly collected residual waste, paper and organic waste, there will soon be a line for orange peels, coffee grounds and foil. Smart collection is concerned with the issue of how we can collect waste separately at the source in an efficient and sustainable way, without the inner-city environment silting up with trucks. ${ }^{26}$ Antwerp in Belgium encourages residents and visitors to throw their waste in the trash can outside the home as well. By scanning the packaging, they can save digital coins that they can cash in at local merchants. ${ }^{27}$

Another puzzle piece consists of stimulating initiatives. For example, the municipality of Haarlemmermeer is the first municipality in the Netherlands to use circular asphalt in a motorway. The supplier of the asphalt, construction company Dura Vermeer, only uses residual waste for the asphalt mixture, and does not add any new products to it ${ }^{28}$. Another example of stimulation can be found in the Walloon Region in Belgium. Use the waste of one SME as raw material for another SME. Promote reuse or recycling instead of incineration. Reducing unnecessary transport ... These are the objectives of a circular economy pilot project that is being carried out in a zoning plan in the Liège region. This project, initiated by the walloon minister for Sustainable Development, aimed to make SMEs network in order to bundle their waste management and promote their recycling or reuse. 29

Ultimately, legislation is a final piece, at whatever level. The public sector is by far the largest customer of the construction sector in Switzerland, accounting for about half of the order volume. It has an important role model function by ordering more recycling material. With the new procurement law that came into effect on January 1, 2021, quality and sustainability should become more important. By also introducing the construction with recycled material in the tender conditions, builders make an effective and concrete contribution. ${ }^{30}$

\section{FINAL REMARKS}

Circular economy can only be successful if companies see a profit model in it, or are forced to change their course by public opinion because of negative perception. We are not yet there: Southern Europe has not yet really developed a recycling economy that can develop profitable activities and therefore act in standalone modus. This is yet the case in Northern Europe. The US, on the other hand, is lagging. This is mainly due to a lack of legislation. Yet it is striking that quality newspapers such as the New York Times regularly refer to the European legislative framework, which has grown from a consensus. The large non-profit organizations also take the European directives as a starting point and example. The stubborn 
refusal of American multinationals to release funds for research to develop business models in that direction made them build an advantage over European companies. This attitude has disrupted the level playing field. We argue that this aspect should also be raised at G-7 and G-20 meetings. This kind of disruptive economy is one that is based on greed and not innovation. It is a dangerous precedent in a world where climate change is the main jammer of the century.

\section{ANNEX 1 - THE DATABASE OF ARTICLES - ALL ARTICLES CAN BE FOUND ON earaercircular.tumblr.com}

\begin{tabular}{|c|c|c|c|c|}
\hline Title & Newspaper & $\begin{array}{l}\text { Country } \\
\text { newspaper }\end{array}$ & $\begin{array}{l}\text { Cases } \\
\text { from }\end{array}$ & Date \\
\hline $\begin{array}{l}\text { Munich International Motor Show: } \\
\text { Now in eco mode }\end{array}$ & $\mathrm{SDZ}^{31}$ & $\mathrm{D}$ & $\mathrm{D}$ & $3 / 09 / 2021$ \\
\hline $\begin{array}{l}\text { Solutex, the most sustainable omega } \\
3 \text { is extracted with } \mathrm{CO} 2 \text { in Aragon }\end{array}$ & El Pais & $\mathrm{E}$ & $\mathrm{E}$ & $2 / 09 / 2021$ \\
\hline The Cotton Tote Crisis & NYT 32 & USA & $\begin{array}{l}\text { USA, } \\
\text { DK; } \\
\text { CDN, S }\end{array}$ & $1 / 09 / 2021$ \\
\hline $\begin{array}{l}\text { Recycling companies are struggling } \\
\text { with high-tech carbon plastic }\end{array}$ & SDZ & $\mathrm{D}$ & $\mathrm{D}$ & $29 / 08 / 2021$ \\
\hline $\begin{array}{c}\text { Universities and Technical } \\
\text { Universities in Brandenburg- } \\
\text { Germany: Climate-conscious and } \\
\text { sustainable }\end{array}$ & SDZ & $\mathrm{D}$ & $\mathrm{D}$ & $28 / 08 / 2021$ \\
\hline $\begin{array}{c}\text { Universities and Technical } \\
\text { Universities in Brandenburg- } \\
\text { Germany: Climate-conscious and } \\
\text { sustainable }\end{array}$ & SDZ & $\mathrm{D}$ & $\mathrm{D}$ & $28 / 08 / 2021$ \\
\hline $\begin{array}{l}\text { Fashion recycling in the Bahnwärter } \\
\text { Thiel in Munich }\end{array}$ & SDZ & D & $\mathrm{D}$ & $26 / 08 / 2021$ \\
\hline $\begin{array}{l}\text { The nasty consequences of fast } \\
\text { furniture }\end{array}$ & Trouw & NL & NL & $21 / 08 / 2021$ \\
\hline $\begin{array}{l}\text { The tasty and ecological copper } \\
\text { business: Telefónica obtains } 131 \\
\text { million with the recycling of cables }\end{array}$ & El Pais & E & $\mathrm{E}$ & $20 / 08 / 2021$ \\
\hline $\begin{array}{l}\text { Things are not yet running smoothly } \\
\text { within the circular economy }\end{array}$ & SDZ & D & $\mathrm{D}$ & $20 / 08 / 2021$ \\
\hline $\begin{array}{l}\text { Belgian multinational Agfa-Gevaert } \\
\text { directly contributes to circular } \\
\text { economy neighborhood initiatives }\end{array}$ & VRTNews & B & B & $17 / 08 / 2021$ \\
\hline $\begin{array}{l}\text { Returns are free, but that sweater } \\
\text { that didn't fit might go into the } \\
\text { incinerator }\end{array}$ & Trouw & NL & NL, UK & $16 / 08 / 2021$ \\
\hline $\begin{array}{l}\text { Ocean Cleanup's second attempt to } \\
\text { remove plastic from the sea is now in } \\
\text { full swing }\end{array}$ & Change Inc & NL & NL & $12 / 08 / 2021$ \\
\hline $\begin{array}{l}\text { Processing } 150,000 \text { tonnes of flood } \\
\text { waste will take up to a year }\end{array}$ & LLB & B & B & $11 / 08 / 2021$ \\
\hline $\begin{array}{c}\text { "Green Amazon" launched by two } \\
\text { Belgians }\end{array}$ & LLB & B & $\mathrm{B}, \mathrm{F}$ & $8 / 08 / 2021$ \\
\hline
\end{tabular}


From Linear to Circular Economy: The Role of Regional Awareness and Initiatives

\begin{tabular}{|c|c|c|c|c|}
\hline $\begin{array}{l}\text { Scarcity of raw materials makes it } \\
\text { more difficult to get a foot on the } \\
\text { housing ladder }\end{array}$ & SDZ & $\mathrm{D}$ & D & $8 / 08 / 2021$ \\
\hline $\begin{array}{l}\text { Water from plastic bottles has } \\
\text { hundred times more impact on the } \\
\text { environment than tap water }\end{array}$ & Change Inc. & NL & $\mathrm{NL}, \mathrm{E}$ & $6 / 08 / 2021$ \\
\hline $\begin{array}{l}\text { Facing Severe Droughts, Developers } \\
\text { Seek to Reuse the Water They Have }\end{array}$ & NYT & USA & USA & $4 / 08 / 2021$ \\
\hline $\begin{array}{l}\text { Plastic bottle tyres: Continental in } \\
\text { favour of using recycled PET }\end{array}$ & SDZ & $\mathrm{D}$ & $\begin{array}{l}\mathrm{D}, \mathrm{USA}, \\
\mathrm{F}\end{array}$ & $3 / 08 / 2021$ \\
\hline $\begin{array}{c}\text { This robot cleans up the beach and } \\
\text { does it better and faster than } \\
\text { humans }\end{array}$ & Change Inc. & NL & USA & $3 / 08 / 2021$ \\
\hline $\begin{array}{l}\text { Will plants also soon remove PFOS } \\
\text { from the soil? }\end{array}$ & De Standaard & B & $\mathrm{B}, \mathrm{F}$ & $31 / 07 / 2021$ \\
\hline $\begin{array}{l}\text { Everything you need to know about } \\
\text { the waste sector in the Netherlands. }\end{array}$ & Change Inc. & NL & NL & $30 / 07 / 2021$ \\
\hline What can cardboard furniture do? & SDZ & $\mathrm{D}$ & $\mathrm{D}$ & $30 / 07 / 2021$ \\
\hline $\begin{array}{l}\text { A circular economy requires greater } \\
\text { national commitment in Spain }\end{array}$ & El Pais & $\mathrm{E}$ & $\mathrm{E}$ & $29 / 07 / 2021$ \\
\hline $\begin{array}{l}\text { 'The ban on washing cars with tap } \\
\text { water was just a foretaste' }\end{array}$ & De Tijd & $\mathrm{B}$ & $\mathrm{B}, \mathrm{L}$ & $27 / 07 / 2021$ \\
\hline $\begin{array}{l}\text { This start-up wants to empower the } \\
\text { business of refurbished mobile } \\
\text { phones and tablets }\end{array}$ & LLB & $\mathrm{B}$ & B & $27 / 07 / 2021$ \\
\hline $\begin{array}{c}\text { At the initiative of Dutch Agricultural } \\
\text { University, science and industry } \\
\text { make hard plastic from agricultural } \\
\text { waste }\end{array}$ & Change Inc. & NL & NL & $26 / 07 / 2021$ \\
\hline $\begin{array}{l}\text { At the initiative of Dutch Agricultural } \\
\text { University, science and industry } \\
\text { make hard plastic from agricultural } \\
\text { waste }\end{array}$ & Change Inc. & NL & NL & $26 / 07 / 2021$ \\
\hline Food waste app & SDZ & $\mathrm{D}$ & DK & $24 / 07 / 2021$ \\
\hline $\begin{array}{l}\text { What is the future for the ruins of } \\
\text { houses after the floods? }\end{array}$ & De Standaard & B & $\begin{array}{l}\text { E, B, } \\
\text { USA }\end{array}$ & $24 / 07 / 2021$ \\
\hline $\begin{array}{l}\text { E-cars are better than their } \\
\text { reputation }\end{array}$ & SDZ & $\mathrm{D}$ & D & $21 / 07 / 2021$ \\
\hline $\begin{array}{l}\text { Maine Will Make Companies Pay for } \\
\text { Recycling. Here's How It Works. }\end{array}$ & NYT & USA & USA & $21 / 07 / 2021$ \\
\hline $\begin{array}{l}\text { Between emergency and ecology, } \\
\text { how to recycle the mountain of } \\
\text { waste formed by the floods? }\end{array}$ & LLB & B & B & $20 / 07 / 2021$ \\
\hline $\begin{array}{l}\text { Iberdrola and Irizar join forces in } \\
\text { electric mobility }\end{array}$ & El Pais & $\mathrm{E}$ & $\mathrm{E}$ & $20 / 07 / 2021$ \\
\hline $\begin{array}{l}\text { 'We really need to get rid of that } \\
\text { plastic now' }\end{array}$ & Change Inc. & NL & A & $16 / 07 / 2021$ \\
\hline Ecological building from old concrete & SDZ & $\mathrm{D}$ & D & $16 / 07 / 2021$ \\
\hline $\begin{array}{l}\text { Clean and safe city center through } \\
\text { smart waste collection and digital } \\
\text { innovation }\end{array}$ & Change Inc. & NL & NL & $15 / j u l / 21$ \\
\hline
\end{tabular}




\begin{tabular}{|c|c|c|c|c|}
\hline $\begin{array}{c}\text { The Beauty Brands Cutting Down on } \\
\text { Packaging }\end{array}$ & NYT & USA & $\begin{array}{l}\text { USA, } \\
\text { DK, I }\end{array}$ & $14 / 07 / 2021$ \\
\hline $\begin{array}{c}\text { Green façade that purifies shower } \\
\text { water and insulates the house? } \\
\text { UGhent pilot project turns out to be a } \\
\text { success }\end{array}$ & VRTNews & B & B & $12 / 07 / 2021$ \\
\hline $\begin{array}{c}\text { Fashion brands are diving into ocean } \\
\text { plastic, but does it really save the } \\
\text { oceans? }\end{array}$ & Knack WE & B & GB & $9 / 07 / 2021$ \\
\hline $\begin{array}{c}\text { Elephant grass stores four times as } \\
\text { much } \mathrm{CO} 2 \text { as a forest. This company } \\
\text { therefore wants to plant it on all } \\
\text { wasteland. }\end{array}$ & Change Inc. & NL & NL & $8 / 07 / 2021$ \\
\hline $\begin{array}{l}\text { Dutch biomass causes deforestation } \\
\text { in Estonia }\end{array}$ & Trouw & NL & NL, EST & $7 / 07 / 2021$ \\
\hline $\begin{array}{l}\text { Dutch Municipality launches } \\
\text { database and marketplace for } \\
\text { circular materials }\end{array}$ & Change Inc. & NL & NL & $7 / 07 / 2021$ \\
\hline Make Brussels an orchard city & LLB & B & B & $5 / 07 / 2021$ \\
\hline $\begin{array}{l}\text { "Now is the time for the deposit on } \\
\text { cans in Wallonia" }\end{array}$ & LLB & B & B & $3 / 07 / 2021$ \\
\hline $\begin{array}{c}\text { Antwerp organises action to throw } \\
\text { waste in the garbage can outdoors as } \\
\text { well }\end{array}$ & De Standaard & B & B & $2 / 07 / 2021$ \\
\hline $\begin{array}{l}\text { True price: the solution for food } \\
\text { prices that are too low }\end{array}$ & Change Inc. & NL & NL & $2 / 07 / 2021$ \\
\hline $\begin{array}{l}\text { Sustainable fashion or a haven for } \\
\text { quacks? }\end{array}$ & De Standaard & B & GB & $30 / 06 / 2021$ \\
\hline $\begin{array}{l}\text { Agricultural poisons are often } \\
\text { unnecessary, as long as there are } \\
\text { natural enemies of the pest species }\end{array}$ & Trouw & NL & NL & $27 / 06 / 2021$ \\
\hline $\begin{array}{c}\text { The obstacle course to 'green' Lego } \\
\text { blocks }\end{array}$ & De Tijd & B & DK, B & $23 / 06 / 2021$ \\
\hline $\begin{array}{c}\text { "Greenwashing is no longer an } \\
\text { option" }\end{array}$ & LLB & B & B & $22 / 06 / 2021$ \\
\hline $\begin{array}{l}\text { The Green Soap Company produces a } \\
\text { sustainable alternative to soap }\end{array}$ & Change Inc. & NL & NL & $20 / 06 / 2021$ \\
\hline $\begin{array}{l}\text { This platform aims to become 'the } \\
\text { Amazon of recycled materials' with } \\
\text { the help of blockchain }\end{array}$ & Change Inc. & NL & NL, F & $18 / 06 / 2021$ \\
\hline $\begin{array}{l}\text { Voka study: circular economy is } \\
\text { becoming contagious }\end{array}$ & Trends & B & B & $16 / 06 / 2021$ \\
\hline $\begin{array}{l}\text { A Second Life for North Carolina's } \\
\text { Shuttered Factories }\end{array}$ & NYT & USA & USA & $15 / 06 / 2021$ \\
\hline $\begin{array}{l}\text { Aluminum coffee capsules can be } \\
\text { recycled forever. Why don't we? }\end{array}$ & Change Inc. & NL & NL & $15 / 06 / 2021$ \\
\hline $\begin{array}{l}\text { Construction removes considerably } \\
\text { more water than previously assumed }\end{array}$ & De Standaard & B & B & $15 / 06 / 2021$ \\
\hline $\begin{array}{l}\text { "Circular concrete" to reduce } \mathrm{CO} 2 \\
\text { emissions in the construction sector }\end{array}$ & LLB & B & B & $12 / 06 / 2021$ \\
\hline
\end{tabular}


From Linear to Circular Economy: The Role of Regional Awareness and Initiatives

\begin{tabular}{|c|c|c|c|c|}
\hline $\begin{array}{l}\text { CEO PreZero Netherlands (formerly } \\
\text { SUEZ) to implement circular strategy } \\
\text { faster }\end{array}$ & Change Inc. & NL & NL, D & $11 / 06 / 2021$ \\
\hline $\begin{array}{l}\text { New Amsterdam port factory } \\
\text { converts non-recyclable waste such } \\
\text { as household waste into methanol }\end{array}$ & Change Inc. & NL & NL & $9 / 06 / 2021$ \\
\hline $\begin{array}{c}\text { From worn-out flip flops in Kenya, to } \\
\text { colorful office bear in the } \\
\text { Netherlands }\end{array}$ & Change Inc. & NL & NL & $4 / 06 / 2021$ \\
\hline "Brands present themselves" & $\begin{array}{l}\text { Magazine } \\
\text { Universiteit } \\
\text { Antwerpen }\end{array}$ & B & B & jun/21 \\
\hline $\begin{array}{l}\text { "We mainly approach sustainability } \\
\text { from the point of view of reusability" }\end{array}$ & $\begin{array}{l}\text { Magazine } \\
\text { Universiteit } \\
\text { Antwerpen }\end{array}$ & B & B & jun/21 \\
\hline $\begin{array}{l}\text { Jef transforms old scout tents into } \\
\text { backpacks }\end{array}$ & $\begin{array}{l}\text { Magazine } \\
\text { Universiteit } \\
\text { Antwerpen }\end{array}$ & B & B & jun/21 \\
\hline $\begin{array}{c}\text { Textile entrepreneur Julie Lietaer: } \\
\text { 'We won't make it with planting } \\
\text { trees alone' }\end{array}$ & De Tijd & B & $\mathrm{B}$ & $1 / 06 / 2021$ \\
\hline $\begin{array}{l}\text { What if you opted for eco- } \\
\text { responsible clothing? }\end{array}$ & LLB & B & B & $31 / 05 / 2021$ \\
\hline $\begin{array}{l}\text { Federation of companies from } \\
\text { Belgium wants to link circular } \\
\text { economy and competitiveness }\end{array}$ & LLB & B & B & $27 / 05 / 2021$ \\
\hline $\begin{array}{l}\text { More and above all high-quality } \\
\text { recycling is how the circular } \\
\text { economy becomes reality }\end{array}$ & Change Inc. & B & NL & $24 / 05 / 2021$ \\
\hline $\begin{array}{l}\text { Is recycling a waste? Here's the } \\
\text { answer from a plastics expert before } \\
\text { you ditch the effort }\end{array}$ & CNBC & USA & USA & $22 / 05 / 2021$ \\
\hline $\begin{array}{c}\text { Sustainable alternatives to } \\
\text { disposable containers are full of } \\
\text { harmful chemicals }\end{array}$ & Trouw & NL & $\begin{array}{l}\mathrm{CZ}, \mathrm{G}, \mathrm{F} \text {, } \\
\mathrm{DK}, \mathrm{NL}\end{array}$ & $20 / 05 / 2021$ \\
\hline $\begin{array}{l}\text { Capital injection Vinted: } 250 \text { million } \\
\text { euros for "circular fashion platform" }\end{array}$ & Change Inc. & NL & $\mathrm{LT}$ & $14 / 05 / 2021$ \\
\hline $\begin{array}{l}\text { Battery recycling easier with new } \\
\text { way to refresh lithium }\end{array}$ & Change Inc. & NL & FIN, NL & $5 / 05 / 2021$ \\
\hline $\begin{array}{l}\text { Nouryon and Renewcell build factory } \\
\text { for upscaling textile recycling }\end{array}$ & Change Inc. & $\mathrm{NL}$ & $\mathrm{S}, \mathrm{NL}$ & $5 / 05 / 2021$ \\
\hline $\begin{array}{c}\text { Second-hand, good for climate and } \\
\text { employment }\end{array}$ & De Standaard & B & LT, B & $4 / 05 / 2021$ \\
\hline $\begin{array}{l}\text { The not so circular journey of } \\
\text { household waste in Spain }\end{array}$ & El Pais & E & $\mathrm{E}$ & $2 / 05 / 2021$ \\
\hline $\begin{array}{l}\text { SEB gives a second life to its } \\
\text { household appliances }\end{array}$ & Ouest France & $\mathrm{F}$ & $\mathrm{F}$ & $23 / 04 / 2021$ \\
\hline $\begin{array}{l}\text { Belgian ports as pioneers of the } \\
\text { circular economy }\end{array}$ & $\begin{array}{l}\text { Belfius } \\
\text { Magazine }\end{array}$ & B & B & $22 / 04 / 2021$ \\
\hline $\begin{array}{c}\text { Repairing electrical appliances is } \\
\text { becoming easier in France and in } \\
\text { Europe }\end{array}$ & InfoduJour & F & F, EU & $20 / 04 / 2021$ \\
\hline
\end{tabular}




\begin{tabular}{|c|c|c|c|c|}
\hline $\begin{array}{l}\text { Circular economy in Switzerland: } \\
\text { building more sustainably together }\end{array}$ & Presse blog & $\mathrm{CH}$ & $\mathrm{CH}$ & $13 / 04 / 2021$ \\
\hline $\begin{array}{l}\text { When what your grandparents did } \\
\text { was the basis of the circular } \\
\text { economy }\end{array}$ & El Pais & $\mathrm{E}$ & $\begin{array}{l}\text { E, NL, } \\
\text { FIN }\end{array}$ & $18 / 03 / 2021$ \\
\hline $\begin{array}{l}\text { When what your grandparents did } \\
\text { was the basis of the circular } \\
\text { economy }\end{array}$ & El Pais & E & $\begin{array}{l}\text { E, NL, } \\
\text { FIN }\end{array}$ & $18 / 03 / 2021$ \\
\hline $\begin{array}{l}\text { Innovations at the service of the } \\
\text { environment: Comet transforms final } \\
\text { car waste into fuel }\end{array}$ & LLB & B & B & $10 / 03 / 2021$ \\
\hline $\begin{array}{l}\text { La cyclerie, a sustainable bicycle } \\
\text { workshop in Liège }\end{array}$ & LLB & B & B & $1 / 03 / 2021$ \\
\hline $\begin{array}{l}\text { The second life of aluminum } \\
\text { packaging }\end{array}$ & LLB & B & B & $1 / 03 / 2021$ \\
\hline Your waste, my resource & LLB & B & B & $1 / 03 / 2021$ \\
\hline $\begin{array}{l}\text { The Bossimé craftsmen rethink local } \\
\text { commerce }\end{array}$ & LLB & B & B & $11 / 02 / 2021$ \\
\hline $\begin{array}{l}\text { The Micro Factory, a workshop } \\
\text { where they share more than tools }\end{array}$ & LLB & B & B & $11 / 02 / 2021$ \\
\hline $\begin{array}{l}\text { Circular Textile Lab: "Scaling up } \\
\text { recycled textiles is essential for } \\
\text { future-proof clothing industry" }\end{array}$ & Change Inc. & NL & NL & $5 / 02 / 2021$ \\
\hline $\begin{array}{l}\text { Recycling in America Is a Mess. A } \\
\text { New Bill Could Clean It Up. }\end{array}$ & NYT & USA & USA & $27 / 01 / 2021$ \\
\hline $\begin{array}{l}\text { How small, sustainable businesses } \\
\text { can impact multinationals }\end{array}$ & Change Inc. & NL & NL & $10 / 11 / 2020$ \\
\hline $\begin{array}{l}\text { With circularity comes } \\
\text { responsibility, and occasionally a } \\
\text { slightly higher price }\end{array}$ & Change Inc. & NL & EUR & $13 / 10 / 2020$ \\
\hline $\begin{array}{l}\text { Second-hand economy much bigger } \\
\text { than expected }\end{array}$ & De Standaard & B & B & $8 / 10 / 2020$ \\
\hline $\begin{array}{l}\text { A recycled product cannot be dirtier } \\
\text { and more expensive }\end{array}$ & De Standaard & B & B & $11 / 08 / 2020$ \\
\hline $\begin{array}{l}\text { Belgian multinational Agfa-Gevaert } \\
\text { directly contributes to circular } \\
\text { economy neighborhood initiatives }\end{array}$ & VRTNews & B & B & $2 / 07 / 2020$ \\
\hline $\begin{array}{l}\text { Urban agriculture is important for } \\
\text { economic recovery }\end{array}$ & De Standaard & B & B & $11 / 05 / 2020$ \\
\hline $\begin{array}{l}\text { Beverage manufacturers in favor of } \\
\text { the deposit }\end{array}$ & Ouest-France & $\mathrm{F}$ & $\mathrm{F}$ & $3 / 07 / 2019$ \\
\hline $\begin{array}{l}\text { Four companies benefiting from the } \\
\text { circular economy }\end{array}$ & $\begin{array}{l}\text { PME Montréal } \\
\text { blog }\end{array}$ & $\mathrm{CDN}$ & $\begin{array}{l}\text { CDN, } \\
\text { USA }\end{array}$ & $25 / 06 / 2019$ \\
\hline $\begin{array}{l}\text { The development of the circular } \\
\text { economy could generate } 50,000 \text { jobs } \\
\text { in Belgium }\end{array}$ & L'Echo & B & B & $19 / 08 / 2018$ \\
\hline $\begin{array}{l}\text { E-Waste Offers an Economic } \\
\text { Opportunity as Well as Toxicity }\end{array}$ & NYT & USA & $\begin{array}{l}\text { THAI, } \\
\text { USA, } \\
\text { JPN }\end{array}$ & $5 / 07 / 2018$ \\
\hline $\begin{array}{c}\text { The Circular Economy of Recycled } \\
\text { Paper }\end{array}$ & NYT & USA & NL & $18 / 11 / 2014$ \\
\hline
\end{tabular}




\section{REFRENCES}

AFP, Les industriels de la boisson favorables à la consigne (Beverage manufacturers in favor of the deposit) in : Ouest-France, 07/07/2019, https://www.ouestfrance.fr/economie/industries/les-industriels-de-la-boisson-favorables-laconsigne-6434050 "The deposit for the recycling of beverage packaging is necessary for a truly circular economy," say the signatories to the forum. The signatories represent Boissons énergisantes France (BEF), Boissons rafraîchissantes de France (BRF), la Maison des eaux minérales naturelles (MEMN), la Fédération du commerce et de la distribution (FCD), la Fédération nationale des boissons (FNB), la Confédération nationale du commerce de gros et international (CGI), du Syndicat des eaux de sources (SES), le Syndicat national du lait de consommation, l'Union nationale interprofessionnelle des jus de fruit, et enfin Citeo.

Anne Masset, "L'Amazon vert" lancé par deux Belges : "Être un entrepreneur 'à impact', c'est encore plus difficile"( « Green Amazon » launched by two Belgians:" Being an 'impact' entrepreneur is even more difficult ") in : La Libre Belgique, 8-08-2021 https://www.lalibre.be/economie/entreprisesstartup/2021/08/08/etre-un-entrepreneur-a-impact-cest-encore-plusdifficile-QOUFTLCTNFB2ZDTCVV2N2D5XDU/

Antonin Marsac, Du "béton circulaire" pour réduire les émissions de CO2 du secteur de la construction (et oublier un fiasco du passé à Bruxelles),( "Circular concrete" to reduce $\mathrm{CO} 2$ emissions in the construction sector) in La Libre Belgique, 12-06-21, https://www.lalibre.be/economie/entreprisesstartup/projet-zin-de-befimmo-du-beton-circulaire-pour-reduire-lesemissions-de-co2-du-secteur-de-la-construction-et-oublier-un-fiasco-dupasse-a-bruxelles-60c378a37b50a6318dca2a2d

Celine Bruyndonckx, Nieuwe woonwijk in Edegem zal verwarmd worden met restwarmte van Agfa-Gevaert,( New residential area in Edegem will be heated with residual heat from Agfa-Gevaert) in: VRT News, do 02 jul 2020, https://www.vrt.be/vrtnws/nl/2020/07/02/woonwijk-edegemverwarmd-door-restwarmte-bedrijf-agfa-gevaert/

Dpa: Hochschulen in Brandenburg: Klimabewusst und nachhaltig, (Universities and Technical Universities in Brandenburg-Germany: Climate-conscious and sustainable) in: Süd-Deutsche Zeitung, 28/8/2021, https://www.zeit.de/news/2021-08/28/hochschulen-in-brandenburgklimabewusst-undnachhaltig?utm_referrer=https\%3A\%2F\%2Fwww.google.be\%2F

https://nl.wikipedia.org/wiki/Innovatietheorie_van_Rogers Rogers' Theory of Innovation (as described in his book Diffusion of Innovations) is a theory that tells something about the diffusion of an innovation (a new product or idea) within a group. The original theory was conceived by Frenchman Gabriel Tarde, but made popular by Everett Rogers

Fnade, la fédération des entreprises du recyclage et du traitement des déchets \& Fédération Federec

Gilles Toussaint, Ton déchet, ma ressource,(Your waste, my resource) in : La Libre Belgique, 1-3-2021

https://stories.lalibre.be/inspire/numero24/index.html

Heleen Bastiaanse: Ja, retourneren is gratis, maar die trui die toch niet paste gaat misschien wel de verbrandingsoven in (Yes, returns are free, but that sweater that didn't fit might go into the incinerator), in: Trouw, 16 August 
2021 https://www.trouw.nl/economie/ja-retourneren-is-gratis-maar-dietrui-die-toch-niet-paste-gaat-misschien-wel-de-verbrandingsoven-

in bcd678f4/

In Spanje heten die puntos limios.

In annex 1 the complete list of articles including their origin

In annex 1 the complete list of articles including their origine

In the US it is referred to as EPR, extended producer responsibility.

Jan Stassijns, Antwerpse actie om afval ook buitenshuis in vuilnisbak te gooien,( Antwerp action to also throw waste in the garbage can outside the home), in: De Standaard, vrijdag 2 juli 2021, https://www.standaard.be/cnt/dmf20210701_97614170

Javier Vadrillo, Iberdrola e Irizar se alían en la movilidad eléctrica,( Iberdrola and Irizar join forces in electric mobility), in: El PAÍS, 20-7-2021 https://cincodias.elpais.com/cincodias/2021/07/20/companias/1626778 110_839044.html

Julio Núñez, Cuando lo que hacían tus abuelos era la base de la economía circular,( When what your grandparents did was the basis of the circular economy) in El Pais, 18-03-2021 , https://elpais.com/sociedad/ecoembes-espacioeco/2021-03-18/cuando-lo-que-hacian-tus-abuelos-era-la-base-de-laeconomia-circular-da-tu-el-siguiente-paso.html

Julio Núñez, Cuando lo que hacían tus abuelos era la base de la economía circular,(When what your grandparents did was the basis of the circular economy) in: El Pais, 18-03-2021, https://elpais.com/sociedad/ecoembesespacio-eco/2021-03-18/cuando-lo-que-hacian-tus-abuelos-era-la-basede-la-economia-circular-da-tu-el-siguiente-paso.html

LLB = La Libre Belgique

Marc Seijlhouwer, Circulaire economie is nog lang geen realiteit in Nederland,( Circular economy is far from a reality in the Netherlands),in : Change Inc, 21 januari 2021, https://www.change.inc/circulaire-economie/circulaireeconomie-nederland-35467

Mariano Ahijado, Un nuevo modelo productivo para llegar a 2030 en buena forma,( A new production model to reach 2030 in good shape) in: El Pais, 17 dic 2020, https://elpais.com/economia/el-futuro-no-se-detiene/2020-1217/un-nuevo-modelo-productivo-para-llegar-a-2030-en-buenaforma.html?utm_source=Facebook\&ssm=FB_CM\&fbclid=IwAR2rQwGtED5 cfUduJZjPFwk8_o29TWz5o21qWsQ7QSjyatPpl7KrtE4GtCU\#Echobox=160 8222521

Michael Kimmelman, Recycling in America Is a Mess. A New Bill Could Clean It Up, in New York Times, Jan. 27, 2021, https://www.nytimes.com/2021/01/27/arts/design/recyclingpackaging-new-york.html?referringSource=articleShare

NYT = New York Times

Patric Van der Haegen, Kreislaufwirtschaft: Gemeinsam nachhaltiger bauen,( Circular economy: building more sustainably together),in: Presse blog, 13. April 2021 https://www.presseblog.com/2021/04/13/kreislaufwirtschaft-gemeinsam-nachhaltigerbauen/

Pierre-François Lovens, Cette start-up qui veut responsabiliser le business des GSM et tablettes reconditionnés (This start-up that wants to empower the 
business of refurbished mobile phones and tablets), in : La Libre Belgique 27-7-2021

https://www.lalibre.be/economie/entreprisesstartup/2021/07/28/la-start-up-belge-qui-veut-responsabiliser-le-

business-des-gsm-reconditionnes-

ZVVW34PNIRFDDHNFESON3NE4SE/\#: :text=Le\%20march\%C3\%A9\%20 du\%20reconditionnement\%20des,carte\%20de\%20la\%20fili\%C3\%A8re\% 20locale.\&text=Son $\% 20$ business $\% 20$ concerne $\% 20$ la $\% 20$ collecte,de $\% 20$ G SM\%20et\%20de\%20tablettes

Romy de Weert: Van afval naar asfalt: gemeente Haarlemmermeer legt circulaire autoweg aan,( From waste to asphalt: Municipality of Haarlemmermeer is building a circular highway), in: Change Inc, 15-12-2020 https://www.change.inc/circulaire-economie/van-afval-naar-asfaltgemeente-haarlemmermeer-legt-circulaire-autoweg-aan-35275

Ruben Mooijman, Duurzame mode of volksverlakkerij?(Sustainable fashion or folklore? J , in: De Standaard, 30-06-2021, https://www.standaard.be/cnt/dmf20210629_97579521

SDZ = Süd-Deutsche Zeiting

Sarah-Mie Luyckx, Machteld Rijnten (53) vindt het tijd dat u leert over de nare gevolgen van fast furniture. 'Weg met de Ikeabank!',(Machteld Rijnten (53) thinks it's time you learned about the nasty consequences of fast furniture. 'Down with the Ikea sofa!) in: Trouw, 21 augustus 2021, https://www.trouw.nl/duurzaamheid-natuur/machteld-rijnten-53-vindthet-tijd-dat-u-leert-over-de-nare-gevolgen-van-fast-furniture-weg-met-deikeabank babede58/

TOM MICHIELSEN , Textielonderneemster Julie Lietaer: 'Met bosjes planten alleen gaan we het niet halen' (Textile entrepreneur Julie Lietaer: 'We won't make it with planting small forests alone'), in: De Tijd, 01 juni 2021, Textielonderneemster Julie Lietaer: 'Met bosjes planten alleen gaan we het niet halen' | De Tijd

Teun Schröder, Gemeente Apeldoorn lanceert database en marktplaats voor circulaire materialen,( Municipality of Apeldoorn launches database and marketplace for circular materials), in: Change Inc, 7 juli 2021, https://www.change.inc/circulaire-economie/gemeente-apeldoorndatabase-marktplaats-circulaire-materialen-36725

Teun Schröder, Schone en veilige binnenstad door slimme afvalinzameling en digitale innovatie,( Clean and safe city center through smart waste collection and digital innovation), in: Change Inc., 15 juli 2021, https://www.change.inc/circulaire-economie/schone-veilige-binnenstadslimme-afvalinzameling-digitale-innovatie-36783

Valentine Van Vyve, La Fabrique Circuit Court, le chaînon manquant pour les petits producteurs,( La Fabrique Circuit Court, the missing link for small producers), in : La Libre Belgique, 02-08-2021, https://www.lalibre.be/planete/inspire/2021/08/02/la-fabrique-circuitcourt-le-chainon-manquant-pour-les-petits-producteursVQGQHRUR75HJTPJKJJMID5JBUY/?fbclid=IwAR3mC2ETAq8VpcJKThehx2iqsl1QPsg18HVOdfDMYVXHpl6vEz707VwbHk

Vincent Ayotte, «Quatre entreprises qui tirent profit de l'économie circulaire » ( Four companies that benefit from the circular economy) in : PME Montréal blog, 25 juin 2019, https://pmemtl.com/blogue/quatre-entreprises-quitirent-profit-de-l-economie-circulaire 